\title{
CUDZE GANICIE, SWEGO NIE ZNACIE... KONCEPCJE KRAJOBRAZU W DWUDZIESTOLECIU MIĘDZYWOJENNYM I ICH RECEPCJA W ARCHEOLOGII OSADNICTWA
}

\author{
THE GRASS IS GREEN NEITHER HERE NOR ON THE OTHER \\ SIDE OF THE FENCE. PRE-WAR IDEAS OF LANDSCAPE \\ AND THEIR RECEPTION IN SETTLEMENT STUDIES
}

\author{
Lidia $\dot{Z} u k$ \\ Instytut Prahistorii, Uniwersytet im. Adama Mickiewicza \\ ul. Św. Marcin 78, 61-809 Poznań, Poland
}

\begin{abstract}
It is commonly assumed that landscape studies is a foreign development to Polish archaeology. The idea of landscape is strongly associated with British school of thoughts, while Central European settlement studies are regarded as deeply rooted in German tradition of Siedlungsarchäologie. However, an insight into their origins in Poland reveals a completely different picture. Concepts of landscape were lively debated among geographers and historians in the pre-war period within the frameworks of the then dominant theories of anthropogeography and evolutionism. This led to the development of a school of thought known as historical geography one of whose basic aims was to reconstruct past cultural landscapes through settlement studies. The aim of this paper is to demonstrate that theoretical and methodological frameworks of settlement archaeology, which were established in the 1960s and 1970s, sprang from historical geography and initially also aimed towards reconstruction of prehistoric landscapes. Polish cases will be then compared and contrasted with contemporary British and German traditions. This will help determine at which points these traditions differ, what may be the reason for those differences and what can we learn from these pre-war developments.
\end{abstract}

(...) osadnik wczesny nie miat już dookoła siebie krajobrazu pierwotnego. Odziedziczyt on bowiem pewien krajobraz kulturalny po dawniejszych czasach przedhistorycznych ${ }^{1}$.

\section{WPROWADZENIE}

W polskiej tradycji badawczej nurt studiów nad krajobrazem wydaje się nieobecny. Od lat 60 . na styku człowiek-środowisko przyrodnicze panują badania osad-

\footnotetext{
${ }^{1}$ Dylik 1936, 67.
} 
nicze, ukształtowane z jednej strony pod wpływem niemieckiej archeologii osadnictwa, z drugiej zaś w wyniku oddziaływań historyków średniowiecza ${ }^{2}$. Ich ostateczny kształt został nadany w pracach W. Hensla, A. Dymaczewskiego, S. Kurnatowskiego i J. Kruka ${ }^{3}$. W powszechnym przekonaniu studia osadnicze są rysem charakterystycznym archeologii środkowoeuropejskiej, przeciwstawianym często tradycji anglosaskiej, w szczególności zaś brytyjskiej, z którą są utożsamiane badania nad krajobrazem. Wrażenie obcości może dodatkowo potęgować wydanie najnowszego kompendium archeologicznego, w którym hasło „krajobraz” w całości opiera się na koncepcjach filozofów francuskich ${ }^{4}$, leżących u podstaw pracy C. Tilleya ${ }^{5}$, a bardziej wnikliwi czytelnicy są odsyłani do podręcznikowego opracowania pod redakcją B. Davida i J. Thomasa ${ }^{6}$. W optymistycznym wariancie polska archeologia do studiów nad krajobrazem mogłaby dojść za czas jakiś, po drodze testując inne propozycje archeologii brytyjskiej, głównie zaczerpnięte z geografii ekonomicznej ${ }^{7}$.

Tymczasem w polskich pracach kształtujących refleksję nad osadnictwem zwracano uwagę, iż stanowią one pierwszy etap badań, których ostatecznym celem jest określenie wpływu osadnictwa na kształtowanie krajobrazu ${ }^{8}$. Szczególnie obecność postulatu, iż studia osadnicze mają w konsekwencji prowadzić do rekonstrukcji krajobrazu kulturowego, może nieco zaskakiwać w sztandarowych pracach osadniczych. Jednak bliższa analiza źródeł tych idei sugeruje, że jest ona naturalną konsekwencją rozwoju koncepcji, które pojawiły się w środowisku polskich geografów i historyków średniowiecza. Celem niniejszego artykułu jest próba wykazania, że studia osadnicze tkwią swymi korzeniami w przedwojennej propozycji geografii historycznej, której jednym z podstawowych zadań była rekonstrukcja krajobrazu „kulturalnego". Analiza przedwojennych propozycji zostanie ograniczona do tych badaczy, których sami archeolodzy uznali za szczególnie inspirujących. Natomiast w aspekcie archeologicznym w szczególności uwzględnione zostaną prace ośrodka poznańskiego, gdyż w tym przypadku można wykazać istnienie bezpośredniej ciągłości między przedwojennymi koncepcjami krajobrazu a późniejszym rozwojem studiów osadniczych w latach 60. „Odtworzenie” podstaw teoretycznych programu studiów osadnictwa pozwoli odpowiedzieć na pytanie, w jakim zakresie archeolodzy rozważali wpływ społeczności pradziejowych na kształtowanie krajobrazu, a tym samym: jak rozumiano krajobraz. Koncepcje te zostaną przedstawione w kontekście

\footnotetext{
${ }^{2}$ Rączkowski 1990, 56.

${ }^{3}$ Rączkowski 2001, 164.

${ }^{4}$ Iwaniszewski 2012.

${ }^{5}$ Tilley 1994.

${ }^{6}$ David, Thomas 2010.

${ }^{7}$ Valde-Nowak 2001, 169, 170, 178.

${ }^{8}$ Kurnatowski 1968, 183; Kruk 1973, 7.
} 
współczesnych im prac naukowców brytyjskich i niemieckich, co w konsekwencji pozwoli stwierdzić, w jakim stopniu rzeczywiście te tradycje są odmienne i gdzie ewentualnie tkwią przyczyny tych odmienności.

\section{KRAJOBRAZ W UJECIU GEOGRAFII HISTORYCZNEJ}

\section{Aspekt (pra)historyczny w studiach nad krajobrazem}

Od lat 20. XX w. w środowisku polskich historyków i geografów zaczął pojawiać się postulat badania krajobrazu kulturalnego w ramach tzw. geografii historycznej. Jej zadania kształtowały się stopniowo $\mathrm{w}$ toku debaty nad rolą geografii w badaniach historycznych. Pod wpływem inspiracji płynących z kręgu antropogeografii F. Ratzla podjęto próbę określenia wpływu czynników środowiskowych na dzieje ludzkie 9 . Jednocześnie zainteresowanie aspektem historycznym w studiach nad krajobrazem było naturalną konsekwencją akceptacji określonych założeń teoretycznych. W toku rozwoju refleksji nad zadaniami antropogeografii zauważono konieczność uwzględnienia elementów ewolucjonizmu, co miało umożliwić badanie przeszłych stanów danego zjawiska (stadiów rozwojowych): „(a)żeby zrozumieć bowiem daną formę, trzeba poznać jej początki i rozwój. Zbadanie ich związku z warunkami geograficznemi wymaga cofnięcia się do tych okresów historycznych, w których one powstały, poznania ówczesnego krajobrazu i ówczesnych warunków życia. Zadanie to nawskroś historyczne"10. W wymiarze praktycznym konieczność uwzględnienia aspektu historycznego w studiach nad krajobrazem była uzasadniana długotrwałym rozwojem form osadnictwa i gospodarki na obszarze Polski. W konsekwencji spowodowało to współwystępowanie zjawisk osadniczych z różnych okresów, np. obok reliktów średniowiecznych systemów pól mogły pojawić się nowe układy przestrzenne, powstałe w wyniku parcelacji wielkich majątków ziemskich. Toteż postulat włączenia badań historycznych do studiów nad krajobrazem pojawił się stosunkowo wcześnie, a dane historyczne od początku odgrywały ważną rolę (choć nie było to oczywiste dla wszystkich geografów) ${ }^{11}$.

Punktem wyjścia do realizacji tego celu była rekonstrukcja krajobrazu naturalnego oraz zachodzących $\mathrm{w}$ nim zmian pod wpływem działalności człowieka. W dalszej perspektywie umożliwiało to badanie dynamiki krajobrazu kulturalnego i określenia czynników go kształtujących. Krajobraz stał się pojęciem podstawowym dla rozstrzygnięcia takich kwestii, jak wpływ warunków środowiskowych na dzieje społeczności ludzkich, kierunki migracji, procesy osadnicze, działalność gospodar-

\footnotetext{
${ }^{9}$ Semkowicz 1925, 1; Arnold 1929, 92.

${ }^{10}$ Mrazek-Dobrowolska 1930, 280.

${ }^{11}$ Labuda 1953, 8.
} 
czą i kulturalną, a także powstawanie i rozwój różnych jednostek terytorialnych ${ }^{12}$. Jednak w odróżnieniu od antropogeografii, geografia historyczna miała w praktyce skoncentrować się na badaniu przeszłych relacji między człowiekiem i środowiskiem przyrodniczym. Była ona „nauką, która, przedstawiając dzieje krajobrazu kulturalnego i historyczno-politycznego, bada oddziaływanie danego środowiska geograficznego na rozwój faktów życia społecznego w przeszłości”" ${ }^{\text {"13 }}$. Zainteresowanie historią miało zatem wynikać z samych zadań antropogeografii. W środowisku geografów historycznych konsekwentnie panowała zgodność co do tego, iż w studiach nad krajobrazem kulturalnym również badania archeologiczne były niezbędne. W części metodycznej tych prac stale powracającym punktem była konieczność włączenia źródeł archeologicznych, obok źródeł historycznych, materiałów kartograficznych, toponomastycznych, a także przyrodniczych ${ }^{14}$. Stanowisko to najtrafniej zostało podsumowane w wypowiedzi Arnolda: „bez badań archeologicznych nie można dzisiaj mówić o jakichkolwiek pracach z zakresu dziejów osadnictwa" (sic!) ${ }^{15}$. W odniesieniu do źródeł archeologicznych podkreślano ich szczególną rolę w rekonstrukcji krajobrazu pierwotnego. Badanie pradziejowych społeczności miało umożliwić odtworzenie tych zależności, które w wyniku późniejszego rozwoju ekonomicznego i społecznego zostały zatarte. Od początku zatem dostrzegano potrzebę włączenia archeologii do studiów nad krajobrazem ${ }^{16}$. Za największą słabość źródeł archeologicznych zgodnie też uznano ich słaby stan rozpoznania, co można poniekąd rozumieć jako postulat pod adresem archeologów o podjęcie badań w tym zakresie.

\section{Koncepcje krajobrazu}

Świadomi ograniczeń poznawczych determinizmu geograficznego, polscy badacze rozważali również tezy posybilizmu geograficznego sformułowane przez P. Vidala de la Blache, który zwracał uwagę na wzajemne relacje zachodzące między człowiekiem i środowiskiem geograficznym ${ }^{17}$. Warunki przyrodnicze wyznaczają kierunki ludzkiej działalności, ale jednocześnie człowiek poprzez swoje dzia-

${ }^{12}$ Semkowicz 1925, 1.

${ }_{13}^{13}$ Arnold 1929, 95.

${ }^{14}$ Np. Semkowicz 1925, 6-8; Arnold 1929, 108-110; Mrazek-Dobrowolska 1930, 280.

${ }^{15}$ Arnold 1929, 110.

${ }^{16}$ Semkowicz 1925, 6-8.

${ }^{17} \mathrm{~Np}$. Arnold 1929, 92, 94. Na gruncie historii antropogeografia została poddana gruntownej krytyce dopiero po drugiej wojnie światowej (Labuda 1953). W tym okresie zaczęła coraz bardziej tracić na znaczeniu także w środowisku geograficznym (Kurnatowski 1978, 151). Jednak w kontekście archeologii powojenny rozwój tego nurtu ma mniejsze znaczenie, ponieważ zręby koncepcji studiów nad krajobrazem zostały ukształtowane w okresie międzywojennym i pozostały one bez większych zmian w obliczu późniejszych dyskusji teoretycznych. 
łania wywołuje określone zmiany w środowisku. Toteż cywilizacja ludzkości jest efektem walki człowieka z siłami przyrody, którą człowiek toczy za pomocą wytwarzanych narzędzi ${ }^{18}$. Co jednak istotne $\mathrm{z}$ perspektywy studiów nad społecznościami pradziejowymi: relacje te są zmienne w czasie. „W społeczeństwach pierwotnych obserwuje się ścisłą zależność człowieka od warunków fizjograficznych; formy osadnicze, typy gospodarcze i twory polityczne są ściśle związane $\mathrm{z}$ danym typem fizjograficznym. W miarę rozwoju kultury stosunki te silnie się komplikują. Wzajemne oddziaływanie człowieka i środowiska - nawet jeżeli sobie wyobrazimy idealny rozwój ewolucyjny - zmienia zasadniczo oba badane czynniki. Walka z przyrodą wywiera na umysłowość człowieka znaczny wpływ, z drugiej strony i krajobraz ulega zasadniczej przemianie skutkiem działalności człowieka, wyposażonej w coraz to nowe zdobycze techniczne"19. Taką zależność mogło np. ilustrować rozmieszczenie działalności gospodarczej i osadniczej w stosunku do gleby. W początkowych etapach rozwoju gospodarki rolniczej społeczności „pierwotne” miały wybierać gleby piaszczyste ze względu na łatwość uprawy, natomiast wraz z postępem technicznym i rozwojem narzędzi rolniczych przemieszczano się na żyzne gleby lessowe i czarnoziemy ${ }^{20}$. W takim ujęciu wydaje się, że determinizm i posybilizm traktowano jako teorie komplementarne, adekwatne do opisu różnych etapów ludzkich dziejów. Zgodnie z tym można sformułować dwa podstawowe założenia, które wpłynęły na rozumienie krajobrazu:

a) zależność człowieka od warunków geograficznych jest uwarunkowana stopniem rozwoju cywilizacji - im cywilizacja jest mniej zaawansowana, tym zależność od środowiska jest większa;

b) poziom eksploatacji środowiska naturalnego jest zależny od poziomu rozwoju technicznego - im prostsze narzędzia, tym możliwości wykorzystania zasobów naturalnych są bardziej ograniczone.

Toteż krajobraz był początkowo utożsamiany ze środowiskiem przyrodni$\mathrm{czym}^{21}$, na który składała się suma elementów fizycznych, takich jak: rzeźba terenu, hydrografia i szata roślinna. Celem historyka była zaś rekonstrukcja krajobrazu pierwotnego ${ }^{22}$. Z czasem, gdy zasadniczym celem stało się badanie krajobrazu kulturalnego, zakres tego pojęcia został poszerzony o aspekt humanistyczny ${ }^{23}$. „Jeżeli środowisko przyrodnicze wskazuje działalności twórczej człowieka pewne kierunki i formy, to odwrotnie także człowiek oddziałuje na środowisko, w którem żyje, a obrazem jego działalności jest przemiana krajobrazu pierwotnego w kulturalny"24.

\footnotetext{
${ }^{18}$ Labuda 1953, 15-17.

${ }^{19}$ Mrazek-Dobrowolska 1930, 278.

${ }^{20}$ Mrazek-Dobrowolska 1930, 280.

${ }^{21}$ Kiełczewska-Zaleska 1968, 52.

${ }^{22}$ Semkowicz 1925, 2.

${ }^{23}$ Arnold 1929, s. 95; Mrazek-Dobrowolska 1930, 280.

${ }^{24}$ Mrazek-Dobrowolska 1930, 278.
} 
Odwołując się do stwierdzeń niemieckiego badacza J. Wimmera, Arnold wyróżnił trzy typy krajobrazów ${ }^{25}$ :

a) naturalny, czyli zespół czynników fizjograficznych, kształtujących dane terytorium: geomorfologia, geologia (szczególnie w aspekcie kształtowania gleb), klimat oraz szata roślinna;

b) kulturalny, czyli wszelkie przeobrażenia, które zostały wprowadzone przez człowieka $\mathrm{w}$ efekcie procesów osadniczych, związanych $\mathrm{z}$ habitacją (zakładanie osad) i działalnością gospodarczą (np. zmiany w zasięgu lasów);

c) historyczno-polityczny, czyli wszelkie podziały przestrzeni, związane z rozwojem terytorialnym i organizacją polityczną danej społeczności. Krajobraz ten był „pozostałością" po pierwotnych zadaniach geografii historycznej, do których należało m.in. opracowanie i przedstawienie zmian terytorialnych państw oraz ich podziałów administracyjnych ${ }^{26}$.

W podobny sposób zagadnienie krajobrazu ujmuje M. Dobrowolska. Wprawdzie definicja tego pojęcia pojawiła się $\mathrm{w}$ jej publikacjach dopiero $\mathrm{w}$ okresie powojennym, jednak w przypadku tej badaczki można zauważyć konsekwentne postulowanie określonego programu badań krajobrazu kulturalnego w ramach antropogeogra$\mathrm{fii}^{27}$. Dobrowolska pisze, że „Pojęcie krajobrazu (...) obejmuje podłoże geograficzne wraz z zespołem wszystkich elementów i układów przestrzennych (gospodarczych, osadniczych, społeczno-politycznych), wnoszonych przez działania szeregu generacji na powierzchnię ziemi w wyniku stosowanych przez nie sposobów produkcji” ${ }^{28}$.

W obu definicjach wyraźnie wyróżniają się dwa „komponenty” krajobrazu: naturalny oraz „kulturalny”. Szczególnie interesujący jest rodzaj zmian „kulturalnych” wprowadzonych do krajobrazu pod wpływem działalności człowieka. Ponieważ geografia historyczna koncentrowała się na relacjach między człowiekiem a środowiskiem przyrodniczym, szczególną uwagę poświęcono tym sferom działalności, w których dochodzi do bezpośredniej interakcji między tymi dwoma czynnikami. „Warunki fizjograficzne wyciskają swoje piętno na zjawiskach, silniej z ziemią związanych, jakoto na rozmieszczeniu ludności, na osadnictwie i stosunkach gospodarczych" ${ }^{29}$. Toteż cechą charakterystyczną tej koncepcji jest ograniczenie działalności kulturalnej człowieka w krajobrazie do aspektu osadniczego i gospodarczego, a w studiach nad krajobrazem szczególne zainteresowanie poświęcano tym dwóm zagadnieniom. W badaniach osadniczych mieściła się z jednej strony problematyka rozprzestrzenienia się człowieka na danym obszarze, eksploatacji zasobów naturalnych, zmian etnicznych, demograficznych i społeczno-gospodarczych, z drugiej zaś

\footnotetext{
${ }^{25}$ Arnold 1929, 93, 95.

${ }^{26}$ Por. Labuda 1953, 5.

${ }^{27}$ Np. Mrazek-Dobrowolska 1930; Dobrowolska 1947, 1953.

${ }^{28}$ Dobrowolska 1953, 58.

${ }^{29}$ Mrazek-Dobrowolska 1930, 278.
} 
położenie topograficzne osad i związane $\mathrm{z}$ tym typy wsi $^{30}$. Wszystkie działania z tym związane prowadziły do zmian w krajobrazie i w konsekwencji do jego przeobrażenia w krajobraz kulturalny. Natomiast sam krajobraz był waloryzowany wyłącznie w kategoriach użytkowych. Zmiany kulturalne wprowadzone do niego były „związane w pierwszym rzędzie z dziejami okupowania i wyzyskania danego obszaru dla celów gospodarczych, a więc zmiany w nawodnieniu, zabagnieniu, zalesieniu, w ilości obszarów zajętych pod uprawę rolną lub inny rodzaj gospodarki (np. hodowlany, ogrodniczy, przemysłowy, itd.) ${ }^{\text {"31 }}$. Jako efekt działalności kulturalnej $\mathrm{w}$ krajobrazie zostają wymienione prace melioracyjne (związane $\mathrm{z}$ wypieraniem wody, regulacją rzek, nawadnianiem i użyźnianiem gleb), przemiany środowiska przyrodniczego, związane z eksploatacją jego zasobów surowcowych, oraz zmiany w szacie roślinnej i zwierzęcej ${ }^{32}$.

\section{STUDIA NAD KRAJOBRAZEM SPOŁECZNOŚCI PRADZIEJOWYCH}

\section{Program geografii prehistorycznej J. Dylika}

Postulat badań nad krajobrazem pradziejowym został zrealizowany w ośrodku poznańskim, w którym od początku lat 20 . XX w. tezy antropogeografii były popularyzowane przez S. Pawłowskiego ${ }^{33}$. Przeniesienie tych koncepcji na grunt archeologii nastąpiło za sprawą jego ucznia, J. Dylika. Oprócz geografii studiował on jednocześnie prahistorię pod kierunkiem J. Kostrzewskiego, co zostało zwieńczone w 1930 r. uzyskaniem stopnia doktora filozofii w zakresie geografii i archeologii ${ }^{34}$. Wzmiankowana rozprawa doktorska była bodajże pierwszą pracą z zakresu osadnictwa pradziejowego ${ }^{35}$. W aspekcie geograficznym Dylik polemizował z poglądami A. Hettnera (ucznia F. Ratzla), natomiast archeologicznym: z E. Wahle, próbując wypracować własne stanowisko odnośnie do relacji między tymi dwiema dyscyplinami $^{36}$. Wskazuje to jednocześnie na znajomość głównych trendów teoretycznych tego czasu ${ }^{37}$. Pierwszy okres jego pracy naukowej, przypadający na lata 1930-1948, był poświęcony zagadnieniom osadnictwa pradziejowego, realizowanego ,w dziedzinie nie uprawianej dotychczas szerzej ani w Polsce, ani w innych krajach geogra-

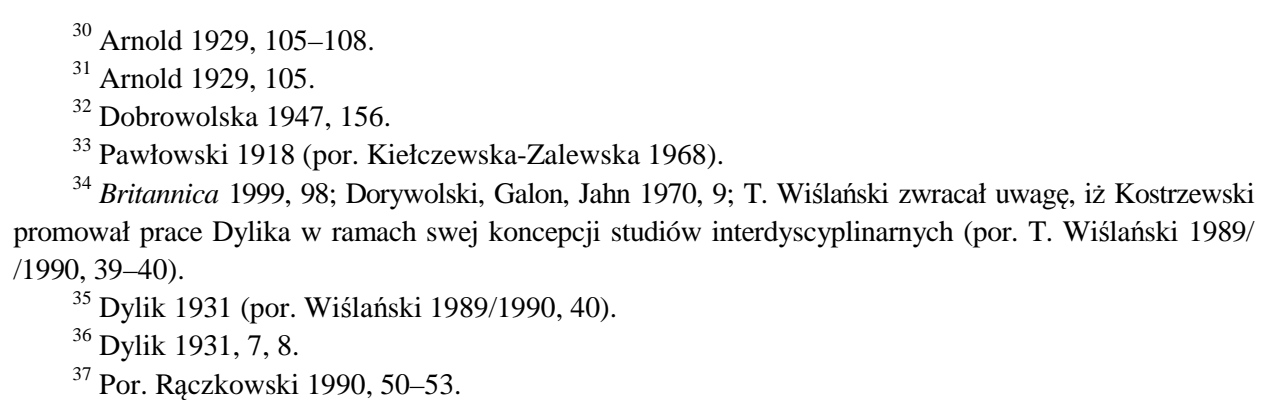


fii prehistorycznej i historycznej" ${ }^{38}$. W tym czasie opublikował w sumie osiem prac poświęconych różnym aspektom osadnictwa pradziejowego, w szczególności zaś neolitowi ${ }^{39}$. W aspekcie metodycznym Dylik również korzystał z osiągnięć ośrodka poznańskiego, uznając badania powierzchniowe za podstawową metodę identyfikacji stanowisk archeologicznych ${ }^{40}$. Natomiast $\mathrm{w}$ gromadzeniu materiałów do rozprawy doktorskiej znaczny udział miało Akademickie Koło Prehistoryków U.P. pod kierunkiem K. Jażdżewskiego ${ }^{41}$.

Zdaniem Dylika badania nad krajobrazem były niezbędne w celu uzyskania pełnego obrazu krajobrazów „minionych”, ale również przy ocenie wartości osadniczej danego obszaru oraz dynamiki procesu (w zakresie zmieniających się potrzeb) ${ }^{42}$. Toteż zadania geografii prahistorycznej określał w następujący sposób: „Celem geografji prehistorycznej jest więc $\mathrm{z}$ jednej strony rekonstrukcja możliwie pełnych krajobrazów minionych, z drugiej zaś wskazanie związków ogólnych między zasadniczemi elementami geograficznemi, mogącemi w zależności od charakteru i sposobu ich powiązania, wytworzyć takie lub inne krajobrazy" "43. Jeśli chodzi o pierwsze zadanie geografii prahistorycznej, to brzmi ono niemal identycznie z celami, jakie postawił geografii historycznej W. Semkowicz. W ujęciu Dylika termin krajobraz odnosi się do fizycznej formy ziemi, na tle której znajdują się ślady ludzkiej działalności. Autor ten pisze, iż „,[n]a całym naszym obszarze posiadamy pewien stały zasób form elementarnych morfologicznych i hydrograficznych, których sposób rozmieszczenia, ilościowe stosunki tegoż rozmieszczenia i wykształcenie indywidualne poszczególnych elementów na tem lub innem miejscu decydują o charakterze takiego czy innego tła krajobrazowego. Fizyczne formy przestrzenne, stworzone przez człowieka, zajmują na tem tle jakieś miejsce, które posiada charakter, określony stosunkiem jakościowym i ilościowym form elementarnych" ${ }^{\text {"44 }}$. W swojej analizie Dylik posługuje się klasyfikacją morfogenetyczną, uznając ukształtowanie za najbardziej podstawowy element, stanowiący substrat wszystkich pozostałych składników krajobrazu geograficznego ${ }^{45}$.

Próbą realizacji drugiego zadania geografii prahistorycznej, czyli określenia relacji pomiędzy elementami tworzącymi dany krajobraz, były artykuły poświęcone osadnictwu. Dylik, podobnie jak inni zwolennicy geografii historycznej, uważał, że zbadanie procesu kształtowania krajobrazu możliwe jest poprzez studia osadnicze. „Osadnictwo prehistoryczne, jak i osadnictwo wogóle, jest wyrazem stosunku czło-

\footnotetext{
${ }^{38}$ Dorywolski, Galon, Jahn 1970, 9,10.

${ }^{39}$ Anonim 1970, 21, 22.

${ }^{40}$ Dylik 1931, 13.

${ }^{41}$ Dylik 1931, 22.

${ }^{42}$ Dylik 1935, 106.

${ }^{43}$ Dylik 1935, 105.

${ }^{44}$ Dylik 1936, 48.

${ }^{45}$ Dylik 1936, 15.
} 
wieka do krajobrazu. Daje ono obraz ustosunkowania się człowieka do warunków geograficznych, i w związku z tem, przez rozwiązanie zagadnienia osadnictwa na jakimś obszarze, stawiamy badania o krok tylko od syntezy geograficznej tegoż obszaru" ${ }^{46}$. Badając zatem czynniki wpływające na osadnictwo, możemy stwierdzić, jak kształtowały się relacje między człowiekiem a jego otoczeniem przyrodniczym, a w rezultacie określić, w jakim zakresie człowiek miał wpływ na kształtowanie krajobrazu. Zdaniem Dylika zagadnienia osadnicze na przestrzeni dziejów są niezmienne, wspólne dla pradziejów, czasów historycznych i współczesnych. Zmianie ulegają jedynie metody (poszukiwań, lokalizacji stanowisk) i ich efektywnośćc ${ }^{47}$. Natomiast różnice w obrazie osadnictwa na różnych etapach dziejów miały wynikać ze zróżnicowanych warunków geograficznych oraz możliwości technicznych. Pogląd taki jest zasadniczo zgodny z założeniami geografii historycznej, toteż zadania osadnictwa pradziejowego określono w następujący sposób ${ }^{48}$ :

a) określenie roli i miejsca osad w krajobrazie;

b) wyjaśnienie relacji zachodzących między osadą i krajobrazem.

Szczególne znaczenie Dylik przypisuje jednak drugiemu zadaniu $-\mathrm{z}$ tego względu, iż miejsce osad w krajobrazie uznaje za stosunkowo stałe (obszary zasiedlenia muszą spełniać określone warunki na przestrzeni dziejów niezależnie od typu zajęć mieszkańców/specjalizacji osady), podczas gdy gospodarka wykazuje się znacznie większą dynamiką ${ }^{49}$. Autor ten wymienia następujące czynniki kształtujące osadnictwo $^{50}$ :

a) budowa geologiczna w aspekcie kształtowania gleby i jej podłoża (szczególna preferencja dla osadów akumulacji rzecznej, głównie piaszczystych);

b) ukształtowanie terenu (dominacja osadnictwa pradziejowego $\mathrm{w}$ dolinach rzecznych i innych „formach wklęsłych”, np. nieckach jeziornych, preferowaną strefą jest stok);

c) woda (jeden z najważniejszych czynników, szczególnie dla kultur łowieckich i pasterskich);

d) klimat i szata roślinna (głównie ze względu na kształtowanie sieci hydrologicznej, aczkolwiek zalecana jest pewna ostrożność przy rozpatrywaniu tego czynnika z powodu jego zmienności);

e) człowiek (czynnik najważniejszy w kształtowaniu osadnictwa, racjonalnie interpretujący możliwości krajobrazowe zgodnie ze swoimi potrzebami).

Warunki przyrodnicze były oceniane z perspektywy ich przydatności dla gospodarki pradziejowych kultur rolniczych i pasterskich. Dlatego w ocenie determinant

\footnotetext{
${ }^{46}$ Dylik 1935, 105.

${ }^{47}$ Dylik 1935, 106.

${ }^{48}$ Dylik 1935, 106.

${ }^{49}$ Dylik 1935, 113.

${ }^{50}$ Dylik 1935, 106-112.
} 
osadniczych szczególnie ważną rolę przypisuje się przede wszystkim położeniu topograficznemu osad. Zasadniczo ograniczało się ono do dolin rzecznych, a zmiana strefy zasiedlenia była interpretowana jako zbieżna ze zmianami klimatycznymi. W konsekwencji osadnictwo było badane w długich przedziałach czasowych (np. od neolitu po okres halsztacki), wyznaczanych rytmem przemian klimatycznych. W ujęciu Dylika człowiek jest jednym z elementów kształtujących osadnictwo, wymienianym wśród wielu czynników przyrodniczych. Uwzględniał on rolę ,czynnika ludzkiego" w dostosowywaniu/przekształcaniu środowiska przyrodniczego do potrzeb osadniczych. W jego praktyce interpretacyjnej to jednak warunki przyrodnicze decydują o kształcie osadnictwa ${ }^{51}$. Stanowisko takie pozornie wydaje się znacznie bardziej deterministyczne, niż miało to miejsce w przypadku innych zwolenników geografii historycznej (np. Arnolda i Dobrowolskiej). W rzeczywistości wymienieni badacze reprezentują te same poglądy, odmienność zaś dotyczy różnych stanów badanego zjawiska. J. Dylik zajmował się bardziej „prymitywnymi” okresami w dziejach ludzkich, podczas gdy S. Arnold - średniowieczem, gdy rola człowieka w kształtowaniu krajobrazu wydawała się znacznie większa (a może łatwiej dokumentowana) niż np. w neolicie. Takie ujęcie pozostawało zatem w zgodności z założeniem antropogeografii o silnym uzależnieniu człowieka pradziejowego od warunków przyrodniczych i jego stopniowym zmniejszaniu w miarę rozwoju technologicznego (por. wyżej). Według Dylika „(...) przy rozpatrywaniu dzisiejszych stosunków antropogeograficznych napotykamy między naturą i człowiekiem rozwinięty silnie czynnik jego wynalazczości (co prowadzi nas w sferę ducha) i potężne wpływy historyczne. Fakt ten utrudnia wykrycie zasadniczych praw, rządzących zależnością człowieka od przyrody, i nadaje antropogrografji inny, bardziej humanistyczny, socjologiczno-historyczny kierunek. Natomiast w geografji prehistorycznej tego rodzaju trudności są minimalne i łatwiej tutaj można się doszukać praw rządzących osadnictwem, jak również zjawiskami z innych dziedzin antropogeografji, ${ }^{52}$. Niezależnie od ostatecznej oceny tej kwestii, nie ulega wątpliwości, że w pozostałych punktach projekt geografii prahistorycznej jest identyczny z propozycją geografii historycznej. Propozycję tę można podsumować w następujących punktach:

a) podstawowym zadaniem jest rekonstrukcja krajobrazu pradziejowego i określenie relacji zachodzących między czynnikami, które go kształtują;

b) posybilizm lub determinizm geograficzny $w$ relacjach człowiek-środowisko przyrodnicze;

c) studia nad krajobrazem ściśle powiązane z badaniami osadniczymi;

d) osadnictwo definiowane jako habitacja i gospodarka, przy czym eksponuje się aspekt gospodarczy kosztem habitacji;

\footnotetext{
${ }^{51}$ Dylik 1933, 203, 204

${ }^{52}$ Dylik 1931, 9.
} 
e) gospodarka ograniczona do rolnictwa i pasterstwa, stąd szczególne znaczenie jest przypisywane położeniu topograficznemu osad, klimatowi i glebom;

f) ograniczenie strefy eksploatacji gospodarczej do dolin rzecznych ze względu na czynniki naturalne i możliwości techniczne społeczności pradziejowych;

g) wszelkie ślady archeologiczne, niezależnie od ich charakteru (osada, grób, znalezisko luźne), są traktowane jako przejaw osadnictwa, ergo gospodarczej eksploatacji tego obszaru.

Studia nad krajobrazem i osadnictwem pradziejowym w ramach geografii prahistorycznej były z jednej strony odpowiedzią na postulaty płynące ze środowiska geografów historycznych, z drugiej zaś pewną propozycją badawczą, wysuniętą pod adresem archeologów. Pozostawała też w pełnej zgodności z przyjętymi założeniami teoretycznymi oraz metodycznymi geografii historycznej. Koncepcja krajobrazu pojawiła się w kręgu zainteresowań historyków i geografów pod wpływem dominującej $\mathrm{w}$ okresie międzywojennym w naukach przyrodniczych antropogeografii, w wersji zmodyfikowanej wpływami ewolucjonizmu. W ramach tego nurtu szczególny nacisk położono na badanie relacji między człowiekiem i środowiskiem przyrodniczym. Ze względu na ówczesne poglądy o kulturze aktywność człowieka została zredukowana do gospodarki (głównie rolnictwa) i jej skutków: zmian w stosunkach wodnych (nawodnieniu, zabagnieniu), zalesieniu, wielkości obszaru zajętego pod uprawę rolną lub inny typ gospodarki (np. hodowlaną, ogrodniczą itp.). Efektem działalności gospodarczej było powstanie krajobrazu kulturalnego, czyli widocznych pozostałości śladów działalności gospodarczej, oraz przetworzonego podłoża naturalnego i szaty roślinnej. Zainteresowanie krajobrazem pradziejowym wynikało z konieczności uwzględnienia „momentu historycznego” w rozwoju krajobrazu kulturalnego ${ }^{53}$. Natomiast poglądy o pradziejowej działalności człowieka w krajobrazie zostały ukształtowane w dużej mierze na przekonaniu o istotnym stopniu zależności człowieka od warunków przyrodniczych na „niższym” poziomie rozwoju kulturalnego. W konsekwencji w badaniach osadniczych szczególną rolę przypisywano czynnikom naturalnym (położenie topograficzne, gleby, klimat), a zakres przestrzenny badań ograniczano do dolin rzecznych.

\section{Archeologia osadnictwa w ujęciu S. Kurnatowskiego}

Zarysowany przez Dylika program studiów nad krajobrazem i osadnictwem pradziejowym w ramach geografii prahistorycznej początkowo nie spotkał się z większym zainteresowaniem wśród archeologów. Z okresu przedwojennego jedyną odpowiedzią była krytyczna recenzja pracy poświęconej analizie rozmieszczenia grodzisk wczesnośredniowiecznych, jednak dotyczyła ona innych zagadnieńn ${ }^{54}$. Do

\footnotetext{
${ }^{53}$ Dobrowolska 1947, 156.

${ }^{54}$ Kowalenko 1936.
} 
kwestii tych powrócono dopiero w latach 60. i 70. w kontekście studiów osadniczych. Próbę wieloaspektowej analizy tego zagadnienia podjął S. Kurnatowski w serii artykułów ${ }^{55}$. W pracach tych szczególny nacisk położono na wypracowanie reguł postępowania badawczego, w kwestiach teoretycznych zaś odsyłano czytelnika do literatury przedmiotu, głównie przedwojennych prac historyków, którzy nadali kształt geografii historycznej (K. Potkańskiego, W. Semkowicza, S. Arnolda), oraz kilku publikacji powojennych (M. Dobrowolskiej, G. Labudy, S. Zajączkowskiego), bez jednoznacznego określenia stanowiska autora $w$ tej sprawie ${ }^{56}$. Zagadnienie, $w$ jakim stopniu było ono zbieżne z poglądami wymienionych badaczy, warto rozważyć $\mathrm{w}$ odniesieniu do trzech podstawowych zagadnień: relacji między krajobrazem a osadnictwem, czynników kształtujących osadnictwo oraz wpływu człowieka na krajobraz.

a) Relacje między krajobrazem a osadnictwem

Zagadnienie to zostało explicite podniesione w artykule „Osadnictwo i jego rola w kształtowaniu krajobrazu". W aspekcie kształtowania krajobrazu analiza osadnicza miała do wypełnienia cztery podstawowe zadania ${ }^{57}$ :

- wyznaczenie ram czasowo-przestrzennych okupacji ludzkiej na danym terytorium;

- określenie sposobu oraz stopnia eksploatacji środowiska przyrodniczego;

- określenie zmian zachodzących w ,środowisku kulturalnym” pod wpływem procesów naturalnych i antropogenicznych;

- ,datowanie form zasiedlenia, w których znalazły odbicie przemiany niektórych elementów krajobrazu".

Takie sformułowanie problematyki badawczej jednoznacznie wskazuje, że studia osadnicze były postrzegane jako etap wiodący do odtworzenia krajobrazu. Archeolog miał w tym względzie zając się tym, w czym był najbardziej kompetentny, czyli interpretacją źródeł archeologicznych. Charakterystyczne zresztą jest to, że w dalszej części wzmiankowanej pracy skoncentrowano się na możliwościach poznawczych archeologii i problemach związanych ze specyfiką jej źródeł.

b) Czynniki kształtujące osadnictwo

Jak już wspomniano, w koncepcjach osadnictwa odwoływano się do prac przedi powojennych, inspirowanych szkołą antropogeograficzną. Istotną różnicą w stosunku do prac przedwojennych był postulat uwzględnienia, pod wpływem myśli marksistowskiej, wielu czynników społeczno-ekonomicznych, kształtujących osadnictwo i krajobraz. „Obok stosunków produkcji, grających dużą rolę w kształtowaniu się form osadniczych, należy też wziąć pod uwagę elementy świadomości spo-

\footnotetext{
${ }^{55}$ Kurnatowski 1963, 1966, 1968, 1973, 1975, 1978.

${ }^{56} \mathrm{~Np}$. Kurnatowski 1963, 181-182.

${ }^{57}$ Kurnatowski 1968, 183.
} 
łecznej (...). [M]ogą [one] stanowić dzięki swemu konserwatyzmowi wystarczającą siłę dla dłuższego utrzymania pewnych starszych form osadniczych" ${ }^{, 58}$. Jednak w praktyce badań osadniczych czynniki te nie odgrywały większej roli, co często tłumaczono specyfiką źródeł archeologicznych, w których aspekt społeczny jest nieuchwytny. Tym samym osadnictwo zostało ograniczone do ,procesu okupacji i eksploatacji danego terenu" ${ }^{, 59}$, z akcentem przede wszystkim na aspekt gospodarczy. Ponownie pozostaje to w pełnej zgodności z założeniami geografii historycznej, iż krajobraz jest kształtowany przez działalność gospodarczą.

c) Wpływ człowieka na krajobraz

W aspekcie chronologicznym prace Kurnatowskiego wypełniały lukę między studiami neolitycznymi Dylika a pracami nad osadnictwem późnośredniowiecznym. Jest to szczególnie czytelne w studium nad osadnictwem w dorzeczu Obry. Podobnie jak w przypadku artykułu z 1968 r. już sam tytuł wydaje się sugerować źródła inspiracji i poglądy autora ${ }^{60}$. Podstawą wyodrębnienia mikro-(makro-)regionu osadniczego w zachodniej Wielkopolsce były z jednej strony czynniki geomorfologiczne, stwarzające odmienne warunki dla gospodarki, z drugiej zaś - koncentracja znalezisk pradziejowych i wczesnośredniowiecznych na obszarze dolinnym, przedzielonych pasami pustek. Te dwa czynniki pozwalają wyodrębnić specyficzny region osadniczy, w którym można wyróżnić dwie fazy osadnictwa ${ }^{61}$ :

- od środkowego okresu epoki brązu do wczesnego średniowiecza (X w.);

- kształtowany w wiekach XIV-XV (z okresem przejściowym między XI a XIII w.), trwający praktycznie po czasy współczesne.

Charakterystyczną cechą pierwszej fazy osadnictwa była koncentracja punktów osadniczych na ,wklęsłych formach terenu”, takich jak doliny rzeczne, rynny i kotliny polodowcowe, oraz pustki osadnicze na wysoczyznach ${ }^{62}$. Działalność człowieka miała miejsce na niewielkim odlesionym obszarze. Osady były otoczone przez las, częściowo przerzedzony przez wyrąb drzew, wypas bydła, gospodarkę przerzutowo-żarową czy też zbieractwo. Lokalizacja osad była uwarunkowana rozmieszczeniem gleb (bagiennych, murszowych, mad, lekkich czarnych ziem), gospodarka zaś pozostawała bez większego wpływu na szatę roślinną. Także hodowla nie powodowała większych zniszczeń środowiska. Poza strefą eksploatacji znajdowała się nienaruszona puszcza, tworząca na wysoczyźnie szerokie pasy pustek, rozdzielające poszczególne regiony osadnicze. Jedynie w partiach przykrawędnych dolin rzecznych znajdowały się znaleziska luźne i sepulkralne.

\footnotetext{
${ }^{58}$ Kurnatowski 1963, 182.

${ }^{59}$ Kurnatowski 1963, 182 (za: Arnold 1951, 25).

${ }^{60}$ Kurnatowski 1963.

${ }^{61}$ Kurnatowski 1963, 196; 1968, 186; 1975, 146-150, 152-154.

${ }^{62}$ Kurnatowski 1963, 197.
} 
Symptomy istotnych zmian pojawiają się dopiero we wczesnym średniowieczu. Osadnictwo koncentruje się w jeszcze większym stopniu na obszarach nisko położonych, głównie na terasach zalewowych. Zasadniczą zmianą jest kilkakrotne powiększenie powierzchni stref eksploatacji oraz powiększenie obszaru odlesionego. Wyjątkowo gęsta sieć osadnicza wskazuje, iż mogły w tym czasie powstać większe kompleksy pól, nieprzedzielone lasami. Na większą skalę doszło wówczas do wyniszczenia w tej sferze roślinności leśnej, a uprawą objęto nawet obszary teras zalewowych. Dominującą formą gospodarki stała się uprawa zboża i technika sprzężajna. Przyczyniło się to jednak do dewastacji lekkich gleb próchnicznych, co w konsekwencji przyczyniło się do opuszczenia tych terenów.

Wczesnośredniowieczny przełom techniczny wyznaczał początek drugiej fazy, gdy na obszarach wysoczyzny pojawiła się gęsta sieć osadnicza ${ }^{63}$. Jest to okres wielkiego przełomu technicznego, który doprowadził do trwałego przekształcenia środowiska przyrodniczego. Oprócz ponownego powiększenia strefy eksploatacji, najistotniejszą zmianą było przesunięcie osadnictwa na obszary wysoczyznowe (obszar gleb brunatnych, bielicowych i ciężkich czarnych ziem). Spowodowało to wyręb lasów, które dotychczas nie były eksploatowane (grądy oraz lasy sosnowo-dębowe), a w konsekwencji naruszenie stosunków wodnych. Powstaniu nowych regionów osadniczych na obszarach wysoczyznowych towarzyszyło jednocześnie przerzedzenie lub całkowite opuszczenie obszarów dolinnych. Trzebieże lasów wysoczyznowych spowodowały bowiem naruszenie stosunków wodnych na wysoczyźnie oraz uruchomienie procesów spływu, co w dalszej perspektywie doprowadziło do zabagnienia dolin rzecznych.

W zestawieniu z pracami przedwojennymi okazuje się, iż jest to praktyczna ilustracja tezy o niedostępności terenów wysoczyznowych dla gospodarki pradziejowej i wczesnośredniowiecznej, a w konsekwencji ograniczenia strefy działalności tychże gospodarek do obszaru dolin rzecznych. Nieprzypadkowo też moment przełomowy w charakterystyce osadnictwa datowano na okres wczesnego średniowiecza. Pogląd taki był w pełni zgodny z prezentowanym wyżej stanowiskiem zwolenników geografii historycznej, że dopiero odpowiedni poziom techniczny umożliwiał gospodarczą eksploatację obszarów trudniejszych, za które powszechnie uważano wysoczyzny (zajęte przez urodzajne, ale trudne w uprawie gleby).

Biorąc zatem pod uwagę sformułowanie problemów badawczych w studiach osadniczych, jak również ich praktyczną realizację, można stwierdzić, iż podstawy teoretyczne badań osadniczych zostały ukształtowane pod wpływem koncepcji studiów nad krajobrazem, zaproponowanej przez geografię historyczną. W porównaniu z pracami przedwojennymi znacznie wyraźniejszy jest wpływ posybilizmu, co wydaje się naturalną konsekwencją rozwoju krytycznej refleksji w okresie powojen-

\footnotetext{
${ }^{63}$ Kurnatowski 1963, 199.
} 
nym $^{64}$, a także osłabienia koncepcji geograficznych przez uwzględnienie aspektu humanistycznego. Jednak $\mathrm{w}$ pozostałych punktach program ten można uznać za próbę wypełnienia archeologiczną treścią ram studiów nad krajobrazem, które zostały zakreślone w pracach Dylika. W wyniku przyjętej koncepcji osadnictwa, krajobraz i zmiany w nim zachodzące były rozpatrywane w aspekcie wpływu gospodarczej działalności człowieka na środowisko. Dotyczyło to eksploatacji różnych stref krajobrazowych, ingerencji w szatę roślinną (przemiany krajobrazu „pierwotnego” w naturalny, wycinanie lasów, osuszanie bagien, tworzenie ,przestrzeni otwartych"), zmiany stosunków wodnych i glebowych oraz uruchomienia procesów naturalnych (erozja/niszczenie gleb, spływy, akumulacja). Pozostaje zatem odpowiedzieć na pytanie, w jakim stopniu propozycja ta współbrzmiała z ujęciem krajobrazu $\mathrm{w}$ archeologii brytyjskiej i niemieckich studiach osadniczych.

\section{STUDIA NAD KRAJOBRAZEM W KONTEKŚCIE EUROPEJSKIM}

\section{Koncepcje krajobrazu w archeologii brytyjskiej}

Współczesna pracom Dylika była publikacja C. Foksa The personality of Britain $^{65}$. Jest ona uznawana za pierwszą pracę brytyjską, poświęconą krajobrazowi, choć sam Fox nie używa tego terminu ${ }^{66}$. Uznanie go za inicjatora nowego kierunku wynikało prawdopodobnie ze stworzenia swego rodzaju syntezy aspektu humanistycznego i przyrodniczego w badaniach archeologicznych, a także zbieżności wielu jego idei z poglądami W.G. Hoskinsa, właściwego ojca studiów nad krajobrazem ${ }^{67}$.

Celem pracy Foksa było określenie wpływu czynników geograficznych (takich jak położenie geograficzne, ukształtowanie linii brzegowej, struktura geologiczna i topografia) na kierunki migracji i rozmieszczenie kultur pradziejowych na obszarze Wysp Brytyjskich. Takie sformułowanie problemu jednoznacznie wskazuje na inspiracje antropogeografią F. Ratzla ${ }^{68}$. W swoich badaniach Fox poświęcił szczególną uwagę takim zagadnieniom, jak określenie stref zasiedlenia w stosunku do warunków naturalnych oraz zakres przekształceń antropogenicznych w środowisku, powiązany z aspektem technicznym. Wśród podstawowych czynników kształtujących strefy zasiedlenia wymienia on klimat, florę i faunę. O ile klimat miał wyznaczać maksymalny zasięg osadnictwa (szczególnie na obszarach górskich), o tyle szata roślinna, w powiązaniu z czynnikami edaficznymi, decydowała o „mikrotopografii” osadnictwa. Zagadnienie to zostało przeanalizowane na przykładzie osadnictwa

\footnotetext{
${ }^{64}$ Por. Labuda 1953.

${ }^{65}$ Fox 1932.

${ }^{66}$ Rączkowski 2002, 56-57.

${ }^{67}$ Johnson 2007, 34.

${ }^{68}$ Por. Babicz 1962, 61; Rączkowski 1990, 50.
} 
neolitycznego. Zasadniczo koncentrowało się ono na obszarze gleb piaszczystych i żwirowych, a także utworach skał kredowych i wapiennych. Były to gleby lekkie i przepuszczalne, ale także pokryte niezbyt zwartą pokrywą leśną. Dopuszczano możliwość, że na niektórych obszarach lasy nigdy się nie rozwinęły na większą skalę, natomiast na innych terenach dominowały suche lasy liściaste, będące mieszanką dębu, brzozy i jesionu. Zdaniem Foksa nawet osadnicy neolityczni nie mieli problemów z dostosowaniem się do takich warunków. Toteż osadnictwo pradziejowe koncentrowało się na wzgórzach i w wyższych partiach dolin rzecznych. Jednocześnie unikano obszarów występowania wilgotnych lasów dębowych, tworzących „niekończącą się pokrywę leśną z dębu i jesionu, przeplataną podszyciem z cierni, ostrokrzewu i jeżyn”, występujących na obszarach podmokłych, związanych z nieprzepuszczalnymi i ciężkimi glebami gliniastymi ${ }^{69}$. To właśnie połączenie niesprzyjających gleb i zwartej pokrywy leśnej (dodatkowo zamieszkanej przez dzikie i niebezpieczne zwierzęta) sprawiło, że obszary takie były unikane przez całe pradzieje. Niezbyt porośnięte obszary skał kredowych i wapiennych sprzyjały powiększaniu terenów otwartych, niezbędnych dla pasterstwa i rolnictwa. Szczególnie zaś wypas zwierząt zapobiegał regeneracji lasów, które na przestrzeni wieków stopniowo zamieniały się w krajobrazy parkowe, a następnie obszary otwarte. Ogólnie rzecz biorąc, osadnictwo było rozproszone i niezbyt intensywne, skoncentrowane na niewielkich otwartych polanach, usytuowanych na lekkich glebach ${ }^{70}$. Zasadnicza różnica nastąpiła w wyniku ,rosnącej kontroli człowieka nad naturą”, która otworzyła możliwości eksploatacji żyźniejszych obszarów. Fox określił to zjawisko mianem ,zejścia w doliny", ponieważ zaczęto wówczas preferować nisko położone łąki (w dolinach rzecznych) kosztem wyżej położonych pastwisk. W szerszym wymiarze dotyczyło to jednak nie przesunięcia stref osadniczych z suchszych obszarów wyżynnych na dna dolin rzecznych, ale przejścia $\mathrm{z}$ gleb lekkich na urodzajne gleby gliniaste, z obszarów słabiej zalesionych na tereny pokryte gęstym wilgotnym lasem dębowym $^{71}$. Istotnym czynnikiem był tu rozwój techniczny, związany z wprowadzeniem pługu koleśnego $\mathrm{z}$ odkładnicą. Zjawisko to jest datowane na okres osadnictwa Anglosasów, przypadającego na lata 650-1050 n.e., gdy osadnictwo na glebach ciężkich było równie intensywne jak na glebach piaszczystych. „Osadnictwo na takim obszarze zależy od osiągnięcia odpowiedniego poziomu cywilizacji przez społeczności rolnicze. Rozwój na obszarach leśnych wymagał znacznej pracy (wyrąb drzew, usuwanie korzeni)","72.

Zaakceptowanie deterministycznych twierdzeń antropogeografii w sposób istotny zaważyło na refleksji Foksa, ograniczając ją do kwestii dostosowywania się

\footnotetext{
${ }^{69}$ Fox 1932, 49.

${ }^{70}$ Fox 1932, 56.

${ }^{71}$ Fox 1932, 74, 75.

${ }^{72}$ Fox 1932, 71.
} 
człowieka do warunków przyrodniczych i prób osiągnięcia kontroli nad środowiskiem. Pradziejowy człowiek ,był w większym stopniu na łasce środowiska, niż w późniejszych czasach",73, wybierając pod zasiedlenie takie obszary, które nie wymagały zbytniej ingerencji. Toteż jego wpływ był bardzo ograniczony, i dopiero wczesnośredniowieczny rozwój techniczny umożliwił zapanowanie nad naturą. „Stąd postęp od stanu podporządkowania się środowisku do jego kontroli, tzn. od barbarzyństwa do cywilizacji, wyraża się fizjograficznie przez użytkowanie wilgotnych lasów dębowych i ich stopniowego zastępowania polami ornymi" "74.

Krajobraz stał się explicite przedmiotem studiów w pracy W. Hoskinsa ${ }^{75}$. Był on z wykształcenia historykiem, co jest kolejną interesującą zbieżnością z polską tradycją geografii historycznej. Mimo że krajobraz jest wszechobecny w jego pracy, to nigdzie nie podaje definicji tego terminu, traktując go zdroworozsądkowo. Można sądzić, że wynikało to z niechęci tego autora do teorii, którą utożsamiał z ,trudnym do przełknięcia żargonem"76 . Zasadniczym celem jego pracy było zbadanie wpływu człowieka na krajobraz Anglii, począwszy od pradziejów, aż po czasy rewolucji przemysłowej. W niewielkim stopniu zajmował się czynnikami naturalnymi (takimi jak np. geologia czy klimat), ponieważ przedmiotem jego zainteresowania były efekty wielowiekowej działalności człowieka w krajobrazie, których świadectwem były fizyczne pozostałości w postaci pól, lasów, granic, traktów, wsi, miast, kościołów i domów ${ }^{77}$. Takie ujęcie problemu wynikało jednak ze znacznie głębszych przesłanek teoretycznych, niż sam Hoskins byłby skłonny przyznać. Paradoksalnie też jego poglądy są najbardziej czytelne w części dotyczącej pradziejów, potraktowanej najbardziej ogólnikowo i zamkniętej w jednym rozdziale ${ }^{78}$. Niemal zupełne pominięcie tego okresu było efektem przekonania, że bezpośredni wpływ człowieka pradziejowego na krajobraz był niewielki. Wprawdzie zaznaczał się w pewnych częściach Anglii w postaci ciągle widocznych założeń obronnych i wsi, ale zasadniczo nie miał większego znaczenia ${ }^{79}$. Natomiast w obliczu publikacji w latach 60. i 70. XX w. masowych odkryć stanowisk pradziejowych sąd ten nieco zmodyfikował. Jednak pradzieje nadal były pomijane w jego pracach ${ }^{80}$. Większość stanowisk była bowiem niewidoczna na powierzchni ziemi, a ślady pradziejowej działalności człowieka zostały dawno zatarte w wyniku procesów naturalnych i działań następnych pokoleń. „Może się wydawać (...) że w ciągu pięciuset lat, które upłynęły między przybyciem Belgów i odejściem Rzymian, krajobraz naturalny został w znacz-

\footnotetext{
${ }^{73}$ Fox $1932,45$.

${ }^{74}$ Fox 1932, 79.

${ }^{75}$ Hoskins 1955.

${ }^{76}$ Johnson 2007, 56.

${ }^{77}$ Thomas 2005, xvii.

${ }^{78}$ Hoskins 2005, 1-25.

${ }^{79}$ Hoskins 2005, 4.

${ }^{80}$ Hoskins 1976, xxiv-xxv.
} 
nym stopniu przekształcony, ujarzmiony i doprowadzony do użytku jako ziemia uprawna (...). Można by oczekiwać, że po wszystkich tych działaniach uporano się z najtrudniejszym, podczas gdy w rzeczywistości Anglosasi zajęli kraj, który ogólnie rzecz biorąc nadal pozostawał w stanie dzikości. Na pewnych dogodnych obszarach (...) mogli napotkać stosunkowo cywilizowany krajobraz; jednak generalnie musieli zaczynać dosłownie od zera" ${ }^{, 1}$. Według tego badacza wynikało to z faktu, że w momencie opuszczenia wyspy przez Rzymian, opanowany i uporządkowany krajobraz wrócił do stanu pierwotnego, ,ginąc w chwastach, zaroślach i ruinach" 82 . Jego zdaniem krajobraz Anglii został ukształtowany w ostatnich piętnastu stuleciach, począwszy od najwcześniejszego osadnictwa anglosaskiego, datowanego na połowę V w. n.e. ${ }^{83}$. Pisał: „,...) znaczna część osadników angielskich stanęła twarzą $\mathrm{w}$ twarz $\mathrm{z}$ dziewiczym krajem, porośniętym wilgotnymi lasami dębowojesionowymi lub bukowymi na kredzie; tylko zimne i zasnute mgłą wrzosowiska, bagniska, solniska u ujścia rzek i jałowe, suche wrzosowiska nie były pokryte gęstym lasem" ${ }^{\prime \prime}$.

Nawet tak pobieżna analiza pozwala stwierdzić, iż poglądy o niewielkim zasięgu zmian antropogenicznych w pradziejach czy średniowiecznym przełomie ,,anglosaskim" były identyczne z tymi, które ponad dwadzieścia lat wcześniej wygłosił Fox. Takich podobieństw było znacznie więcej, np. w kwestii dominującego modelu gospodarki pradziejowej oraz zajmowania ciężkich gleb gliniastych pod uprawę ${ }^{85}$. Przyczyny dosyć specyficznej selekcji faktów, jakiej dokonał Hoskins w odniesieniu do pradziejów, tkwiły zatem w koncepcji krajobrazu, ukształtowanej pod wpływem antropogeografii. W takim ujęciu oznaczał on sumę elementów kulturowych i przekształceń środowiska naturalnego, które powstały na powierzchni ziemi w toku wielowiekowej działalności człowieka. Konsekwentnie koncentrowano się wyłącznie na materialnych przejawach życia ludzkiego, ograniczając je praktycznie do kwestii gospodarczych. Tradycja ta jest ciągle bardzo silna w brytyjskiej archeologii historycznej, poparta pracami wielu badaczy, takich jak: C. Taylor ${ }^{86}$, M. Aston ${ }^{87}$, A. Fleming ${ }^{88}$ czy R. Muir ${ }^{89}$. Wnikliwej analizie i krytyce została poddana dopiero w pracy M. Johnsona, który podjął próbę przełamania tego modelu, inspirując się propozycją archeologii postprocesualnej w odniesieniu do pradziejów ${ }^{90}$.

\footnotetext{
${ }^{81}$ Hoskins 2005, 23.

${ }^{82}$ Hoskins 2005, 23, 24.

${ }^{83}$ Hoskins 2005, 4.

${ }^{84}$ Hoskins 2005, 25.

${ }^{85}$ Hoskins 2005, 15, 17, 18.

${ }^{86}$ Taylor 1974 (por. Barker, Darvill 1997).

${ }^{87}$ Aston 1985.

${ }^{88}$ Fleming, Hingley 2007.

${ }^{89}$ Muir 2000.

${ }^{90}$ Johnson 2007, 119-161.
} 


\section{Archeologia osadnictwa w ujęciu H. Jankuhna}

W ujęciu H. Jankuhna, uważanego za twórcę archeologii osadnictwa ${ }^{91}$, jednym z podstawowych zadań studiów osadniczych były badania nad krajobrazem kulturalnym. Na gruncie archeologii wskazywał on m.in. na inspiracje pracami E. Wahle, który, czerpiąc z koncepcji Ratzla, postulował jednocześnie wszechstronną analizę czynników kształtujących osadnictwo ${ }^{92}$. Zdaniem Jankuhna archeologiczne badania osadnicze były komplementarne wobec geografii osadnictwa i historii osadnictwa. Szczególnie bliskich związków w aspekcie stosowanych metod i wykorzystywanych źródeł dopatrywał się między archeologią i geografią osadnictwa: „Również geografia osadnictwa - i właśnie ona - bada uwarunkowania osiedla i terenu i w tym zakresie wytyczyła metodyczne drogi archeologii osadnictwa (...). Geografia osadnictwa, podobnie jak archeologia osadnictwa, badała, częściowo w ścisłej współpracy z toponomastyką i historią osadnictwa, procesy osadnicze na poszczególnych terenach" ${ }^{\text {"93 }}$. W okresie kształtowania się archeologicznych studiów osadniczych geografia osadnictwa pozostawała pod wpływem idei O. Schlütera. Badacz ten, w reakcji na deterministyczne tezy szkoły antropogeograficznej, uznał za podstawowy cel studia nad krajobrazem kulturalnym (antropogenicznym), czyli badanie wpływu człowieka na środowisko. ,Niemiecka archeologia osadnicza, nawiązując do poglądów O. Schlütera, dąży do rekonstrukcji krajobrazu antropogenicznego w danym odcinku pradziejów" "94. Archeologia osadnictwa, jako część szeroko pojętych badań osadniczych, miała m.in. odpowiedzieć na pytanie o czynniki kształtujące krajobraz dla tych czasów, dla których tylko ona dysponowała odpowiednimi źródłami. „Ponieważ jednak krajobraz kulturalny ulegał przemianom pod wpływem zmieniających się czynników naturalnych i różnie nasilonej ingerencji ludzkiej, badanie i przedstawienie tego rodzaju rozwoju tak długo pozostanie zadaniem archeologii osadnictwa, póki na jej miejsce nie wkroczą geografia osadnictwa i historia osadnictwa" $"$.

Jankuhn definiuje krajobraz kulturalny jako rezultat zmian dokonanych przez człowieka w krajobrazie naturalnym w wyniku uruchomienia procesów naturalnych oraz przekształceń antropogenicznych ${ }^{96}$. Powstaje zatem pytanie, w jakim zakresie badania osadnicze miały uzupełniać studia nad krajobrazem. Wśród czynników kształtujących osadnictwo autor ten wymieniał warunki środowiska naturalnego, rodzaj gospodarki, umiejętności techniczne oraz liczbę i strukturę ludności. Środowisko geograficzne wyznaczało kierunki działalności człowieka, w zależności od

\footnotetext{
${ }^{91}$ Steuer 2004, 182.

${ }^{92}$ Rączkowski 1990, 53.

${ }^{93}$ Jankuhn [1977] 2004, 20.

${ }^{94}$ Rączkowski 1990, 56 (por. Kiełczewska-Zaleska 1969, 10-11).

${ }^{95}$ Jankuhn 2004, 160.

${ }^{96}$ Jankuhn 2004,160.
} 
wymogów gospodarczych zajmowano różne strefy, natomiast umiejętności techniczne narzucały ograniczenia w eksploatacji środowiska, których nie można było pokonać bez innowacji technicznych. Czynniki demograficzne były istotne w rozwiązywaniu takich zagadnień, jak np. wielkość osady czy rozwój sieci osadniczej, aczkolwiek mogły również mieć pośredni wpływ w pozostałych sferach ${ }^{97}$. Spośród czterech elementów kształtujących osadnictwo trzy odnoszą się zatem bezpośrednio do relacji między człowiekiem i środowiskiem. Od strony „kulturowej” ograniczały się one do gospodarki i techniki. Konsekwentnie krajobraz kulturowy był kształtowany w wyniku gospodarczej działalności człowieka, czytelnej w postaci śladów pól oraz miejsc wydobycia i przetwarzania surowców.

W ujęciu Jankuhna koncepcja krajobrazu kulturalnego nie odbiegała w istotny sposób od propozycji badaczy brytyjskich. Również niemiecki archeolog przyjął założenie o zależności między rozwojem technicznym a możliwościami eksploatacyjnymi środowiska naturalnego przez społeczności pradziejowe. Toteż uwaga odnośnie do gleb: „Ciężkie gleby stwarzają dobre warunki dla celów rolniczych, są jednak silniej zalesione, natomiast gleby lżejsze, łatwiej jałowiejące (...) pokryte rzadkim, dębowo-brzozowym lasem, były łatwiejsze do zagospodarowania przy pomocy prostych narzędzi rolniczych" "98 mogła znaleźć się zarówno w pracy archeologa brytyjskiego, jak i niemieckiego. Archeologia osadnictwa opierała się na szczegółowej rekonstrukcji sieci osadniczej, dokonywanej na podstawie możliwie różnorodnych źródeł: znalezisk grobowych, osiedli, śladów gospodarki rolniczej, miejsc wydobycia i przeróbki surowców, grodów, ośrodków kultowych i miejsc ofiarnych czy wreszcie skarbów ${ }^{99}$. Dopiero na tej podstawie określano wpływ człowieka na środowisko przyrodnicze, czyli zakres przekształcenia środowiska naturalnego w krajobraz kulturalny. Oczywiście istnieją pewne istotne różnice na poziomie metodycznym między tymi dwoma tradycjami badawczymi, jednak zasadniczo nie wpływają one na rozumienie krajobrazu. Podobieństwa zostały zresztą dostrzeżone także przez badaczy niemieckich. Jak zauważył H. Steuer, ,Zgodnie z jego archeologiczno-osadniczą metodą badawczą należało wyjść poza osadę i ogarnąć jej przestrzeń gospodarczą oraz środowisko naturalne, które zostało przez człowieka opanowane i przekształcone. Badania obejmują - oprócz osad, cmentarzysk, ośrodków kultowych i miejsc przeróbki surowca - także najrozmaitsze naturalne przestrzenie użytkowe, jak np. miejsca pozyskiwania surowców (...). Dziś takie ujęcie badawcze nazywa się archeologią krajobrazu (ang. landscape archaeology)" "100. Model ten, ograniczający badania nad krajobrazem do kwestii gospodarczej eksploatacji środowiska, nadal dominuje w niemieckich badaniach osadniczych ${ }^{101}$.

\footnotetext{
${ }^{97}$ Jankuhn 2004, 71.

${ }^{98}$ Jankuhn 2004, 79.

${ }^{99}$ Jankuhn 2004, 21-33.

${ }^{100}$ Steuer 2004, 182 (podkr. - L. Ż.).

${ }^{101}$ Gramsch 1996, 23.
} 


\section{PODSUMOWANIE}

Z przedstawionej analizy wynika, że koncepcja krajobrazu jest głęboko zakorzeniona $\mathrm{w}$ rodzimej tradycji badawczej. Wywodzi się z przedwojennej propozycji geografii historycznej i praktycznie z niej wyrosły studia osadnicze, które upowszechniły się w Polsce szczególnie w latach 60. i 70. XX w. W okresie międzywojennym polska myśl „krajobrazowa” była zgodna z głównymi nurtami europejskimi, kształtowanymi w tym czasie przez antropogeografię Ratzla i jego kontynuatora, Hettnera, czy też posybilizm Vidala de la Blanche. Można wręcz odnieść wrażenie, iż samoświadomość teoretyczna była znacznie bardziej zaawansowana niż w przypadku archeologów brytyjskich. Polscy badacze za stosowne uznawali podejmowanie polemiki z tezami antropogeografii i posybilizmu, w której kształtowali własne, oryginalne propozycje badawcze. W archeologii jest to widoczne w pracach Dylika, który formułował zadania geografii prahistorycznej w odniesieniu (i opozycji) do koncepcji Hettnera czy Wahla, co zaowocowało programem badań osadniczych i krajobrazowych. Dla porównania: w pracach Foksa i Hoskinsa brakuje tak jasno określonej postawy teoretycznej, a wpływy poszczególnych nurtów ujawniają się dopiero po szczegółowej analizie konkretnych twierdzeń odnośnie do rozwoju krajobrazu pradziejowego i historycznego. Paradoksalnie w archeologii polskiej termin „krajobraz” pojawił się znacznie wcześniej niż brytyjskiej, z którą związany jest dopiero od połowy lat $70 .{ }^{102}$. W tym samym czasie w Polsce zaczęto stopniowo odchodzić od tego terminu na rzecz „osadnictwa” ${ }^{, 103}$.

Biorąc pod uwagę założenia teoretyczne, interpretację procesów osadniczych kształtujących krajobraz i ich realizację w studiach nad wybranymi obszarami, w paradygmacie kulturowo-historycznym nie ma istotnych różnic między tradycją środkowoeuropejską i brytyjską. Wręcz przeciwnie - można zaobserwować wiele zbieżności, które są fascynujące, jako że zostały sformułowane niezależnie w różnych ośrodkach badawczych. Można tym samym uznać, że istnieje międzynarodowa, archeologiczna wspólnota komunikacyjna, wynikająca ze wspólnych podstaw teoretycznych. Ukształtowany na gruncie antropogeografii, z silnymi wpływami ewolucjonizmu, krajobraz kulturalny był rozumiany jako suma fizycznych zmian w środowisku naturalnym. Zmiany te miały zachodzić pod wpływem gospodarczej działalności człowieka, na którą składało się głównie rolnictwo (ewentualnie pasterstwo) w różnych formach i o różnym stopniu zaawansowania. Słabo zaawansowana technicznie gospodarka pradziejowa była związana z glebami lekkimi, osadnictwo zaś było mocno rozproszone i tylko w niewielkim zakresie wpływało na kształt krajobrazu. Jedynie w tym przypadku widać różnicę między tymi dwiema tradycjami. Podczas gdy w Europie Środkowej osadnictwo pradziejowe miało się koncentrować

\footnotetext{
${ }^{102}$ David, Thomas 2010, 27.

${ }^{103}$ Kurnatowski 1977.
} 
w dolinach rzecznych, w Anglii ,zeszło" do dolin dopiero w średniowieczu w wyniku przełomu technologicznego. Różnica ta wynika jednak z odmienności fizjograficznych w rozmieszczeniu gleb lekkich i ciężkich, nie zaś przyjętych założeń teoretycznych. Zgodność panuje również odnośnie do średniowiecznego przełomu technologicznego, owocującego ogromnymi zmianami w krajobrazie i jego „otwarciem”. Gdy zatem w archeologii kulturowo-historycznej pisze się o tym, że „osadnik wczesny" odziedziczył po swoich poprzednikach krajobraz wcześniejszy, chodzi głównie o krajobraz „,rolniczy”, powstały w efekcie gospodarczej działalności człowieka: niewielkie prześwietlone polany w obrębie dolin rzecznych, podchodzące w najlepszym wypadku pod krawędź doliny, za którą znajdował się praktycznie nieruszony krajobraz pierwotny.

Różnice między archeologią środkowoeuropejską a brytyjską z pewnością istnieją obecnie. Nie wynikają one jednak z odmiennych tradycji i „obcości” konceptualnej krajobrazu w rodzimej archeologii, lecz z postaw badawczych. Obok ciągle żywego nurtu archeologii kulturowo-historycznej archeologia brytyjska sięga do propozycji, które wydają się znacznie lepiej odpowiadać na problemy współczesnych badań. Szczególnie od początku lat 90. zaczęto poszukiwać nowych ujęć krajobrazu w nawiązaniu do aktualnej myśli teoretycznej, kształtowanej głównie pod wpływem filozofów francuskich. Przykładem mogą być wymienione wcześniej koncepcje fenomenologiczne, hermeneutyczne i poststrukturalistyczne. Poszukiwania te zaowocowały m.in. pracą C. Tilleya, która do dziś jest traktowana jako punkt zwrotny w studiach nad krajobrazem. Współistnienie różnych nurtów i ścieranie się różnych poglądów sprzyja znacznemu ożywieniu debaty, stąd nie może zaskakiwać, iż obecnie ton nadaje właśnie archeologia anglosaska ${ }^{104}$. Tymczasem główny nurt polskiej archeologii osadnictwa zastygł w schematach wypracowanych przed kilkoma dekadami. Model badań ukształtowany w okresie przedwojennym, utrwalony w latach 60. i 70., obowiązuje bez większych zmian praktycznie do dnia dzisiejszego. Postuluje się jedynie wprowadzenie na większą skalę nowinek technicznych, jak np. GIS i wizualizacja ${ }^{105}$. Jedyna próba „dyskusji” z koncepcjami krajobrazu ograniczała się w praktyce do kwestii terminologicznych ${ }^{106}$. Podobnie w archeologii niemieckiej zmiana miała charakter głównie semantyczny (przejście od studiów osadniczych do studiów nad krajobrazem) i ilościowy, podczas gdy założenia teoretyczne pozostały bez zmian. Pod tym względem postawa polskich badaczy przedwojennych wydaje się znacznie bliższa współczesnym archeologom brytyjskim, gdyż bez większych kompleksów sięgano po nowe rozwiązania teoretyczne i konceptualne, próbując zastosować je na gruncie ojczystym. Obecnie propozycje te mogą wydawać się już mocno przebrzmiałe. Jeśli zatem można czerpać jakieś nauki z osiągnięć przedwojennych, to raczej $\mathbf{w}$ zakresie postaw niż teorii i procedur badawczych.

\footnotetext{
${ }^{104}$ Por. David, Thomas 2010.

${ }^{105}$ Np. Kozłowski, Neustupny 2001.

${ }^{106}$ Konopka 2004, 8.
} 


\section{BIBLIOGRAFIA}

Anonim

1970 Spis prac publikowanych Jana Dylika [w:] Problemy czwartorzędu, red. M. Dorywolski, R. Galon, A. Jahn, Łódź, s. 21-27.

Arnold S.

1929 Geografja historyczna, jej zadania i metody, Przegląd Historyczny 28, s. 91-120.

1951 Geografia historyczna Polski, Warszawa.

Aston M.

1985 Interpreting the landscape: landscape archaeology and local history, Oxford.

Babicz J.

1962 Nauka o ludach Fryderyka Ratzla, Wrocław.

Barker K., Darvill T.

1997 Making English landscapes: changing perspectives, Oxford.

Britannica

1999 Dylik Jan [hasło w:] Britannica, edycja polska (10), s. 98-99.

David B., Thomas J. (red.)

$2010 \quad$ Handbook of landscape archaeology, Walnut Creek.

David B., Thomas J.

2010 Landscape Archaeology: introduction [w:] Handbook of landscape archaeology, red. B. David, J. Thomas, Walnut Creek, s. 27-43.

Dobrowolska M.

1947 Dynamika krajobrazu kulturalnego, Przegląd Geograficzny 21, s. 151-203.

1953 Przedmiot i metoda geografii historycznej, Przegląd Geograficzny 25, s. 57-77.

Dorywolski M., Galon R., Jahn A.

1970 Od Redakcji [w:] Problemy czwartorzędu, red. M. Dorywolski, R. Galon, A. Jahn, Łódź, s. 9-14.

Dylik J.

1931 Osadnictwo epoki kamiennej w przełomowej dolinie Warty pod Poznaniem, Badania geograficzne nad Polska pótnocno-zachodnia 6-7, s. 7-57.

1935 O najważniejszych elementach kształtujących obraz przedhistorycznego osadnictwa, Przegląd Geograficzny 15, s. 105-117.

1936 Analiza geograficznego położenia grodzisk i uwagi o osadnictwie wczesnohistorycznem Wielkopolski, Badania Geograficzne 16-17, s. 5-88.

Fleming A., Hingley R. (red.)

2007 Landscape history after Hoskins, t. 1: Prehistoric and Roman landscapes, Oxford.

Fox C.

1932 The personality of Britain: its influence on inhabitant and invader in prehistoric and early historic times, Cardiff.

Gramsch A.

1996 Landscape archeology: of making and seeing, Journal of European Archaeology 4, s. 19-38.

Hoskins W.G.

1955 The making of the English landscape, London.

1976 The making of the English landscape, London.

2005 The making of the English landscape, London.

Iwaniszewski S.

2012 Archeologia krajobrazu [w:] Przeszłość społeczna. Próba konceptualizacji, red. S. Tabaczyński, A. Marciniak, D. Cyngot, A. Zalewska, Poznań, s. 284-291. 
Jankuhn H.

[1977] 2004 Wprowadzenie do archeologii osadnictwa, Poznań.

Johnson M.

$2007 \quad$ Ideas of landscape, Oxford.

Kiełczewska-Zaleska M.

1968 Osiągnięcia Stanisława Pawłowskiego w zakresie geografii człowieka [w:] Stanisław Pawtowski. W dwudziesta piata rocznice zgonu (1940-1965), red. B. Olszewicz, Warszawa, s. 49-62.

1969 Geografia osadnictwa. Zarys problematyki, Warszawa.

Konopka M.

2004 Przedmowa do pierwszego wydania tłumaczenia [w:] H. Jankuhn, Wprowadzenie do archeologii osadnictwa, Poznań, s. 7-9.

Kowalenko W.

1936 Dylik Jan, Analiza geograficznego położenia grodzisk i uwagi o osadnictwie wczesnohistorycznem Wielkopolski. Badania geograficzne, zeszyt 16-17, odbitka stron 86, Poznań 1936 r. (recenzja), Roczniki Historyczne 12, s. 321-333.

Kozłowski J.K., Neustupný E. (red.)

2001 Archeologia przestrzeni. Metody $i$ wyniki badań struktur osadniczych $w$ dorzeczach górnej Łaby $i$ Wisty, Kraków.

Kruk J.

1973 Studia osadnicze nad neolitem wyżyn lessowych, Wrocław.

Kurnatowski S.

1963 Uwagi o kształtowaniu się stref zasiedlenia dorzecza Obry w czasie od środkowego okresu epoki brązu do późnego średniowiecza, Archeologia Polski 8, s. 181-221.

1966 Przemiany techniki uprawy roli w czasach między epoką brązową i wczesnym średniowieczem a rozmieszczenie stref zasiedlenia, Studia $z$ dziejów gospodarstwa wiejskiego 8, s. 92-102.

1968 Osadnictwo i jego rola w kształtowaniu krajobrazu, Folia Quaternaria 29, s. 183-197.

1973 Zakres przestrzenny archeologicznych badań terenowych a przydatność ich dla analizy osadniczej, Biuletyn Informacyjny PKZ 25, s. 9-38.

1975 Wczesnośredniowieczny przełom gospodarczy w Wielkopolsce oraz jego konsekwencje krajobrazowe i demograficzne, Archeologia Polski 20, s. 145-160.

$1978 \quad$ Funkcje analizy osadniczej w procesach badawczych nauk geograficznych i historycznospołecznych ze szczególnym uwzględnieniem archeologii i prahistorii, Przegląd Archeologiczny 26, s. 147-187.

Labuda G.

1953 Uwagi o przedmiocie i metodzie geografii historycznej, Przegląd Geograficzny 25, s. 5-56.

Mrazek-Dobrowolska M.

1930 O historyczne podstawy antropogeografii [w:] Pamiętnik II zjazdu geografów i etnografów odbytego w Polsce w roku 1927, t. 2, red. L. Sawicki, Kraków, s. 278-280.

Muir R.

$2000 \quad$ The new reading the landscape. Fieldwork in landscape history, Exeter.

Pawłowski S.

1918 Antropogeografja, Przeglad Geograficzny 1, s. 121-128.

Rączkowski W.

1990 Osadnictwo społeczności rolniczych epoki brazu i epoki żelaza - problemy teoretyczne, Poznań [maszynopis pracy doktorskiej, Biblioteka Instytutu Prahistorii UAM]. 
2001 Między Jankuhnem a Łowmiańskim: w poszukiwaniu koncepcji studiów osadniczych [w:] Archeologia. Paradygmat. Pamięć, red. D. Minta-Tworzowska, W. Rączkowski, Poznań, s. 163-175.

2002 Archeologia lotnicza: metoda wobec teorii, Poznań.

Semkowicz W.

1925 O potrzebie i metodzie badań nad krajobrazem pierwotnym [w:] Pamiętnik IV zjazdu historyków polskich w Poznaniu, Lwów, s. 1-8.

Steuer H.

2004 Herbert Jankuhn (1905-1990) - życie naukowca w służbie archeologii osadnictwa [w:]

H. Jankuhn, Wprowadzenie do archeologii osadnictwa, Poznań, s. 182-192.

Taylor C.

1974 Fieldwork in Medieval Archaeology, London.

Tilley C.

1994 A phenomenology of landscape: places, paths and monuments, Oxford.

Thomas K.

2005 Introduction [w:] W.G. Hoskins, The making of the English landscape, London, s. xv-xxii.

Valde-Nowak P.

2001 Neolit obszarów górskich. Refleksja geograficzno-osadnicza [w:] Archeologia przestrzeni. Metody $i$ wyniki badań struktur osadniczych $w$ dorzeczach górnej Łaby $i$ Wisty, red. J.K. Kozłowski, E. Neustupný, Kraków, s. 169-181.

Wiślański T.

1989/1990 Józef Kostrzewski jako rzecznik współpracy między naukami, Slavia Antiqua 32, s. 35-67.

THE GRASS IS GREEN NEITHER HERE NOR ON THE OTHER SIDE OF THE FENCE.
PRE-WAR IDEAS OF LANDSCAPE AND THEIR RECEPTION IN SETTLEMENT STUDIES

S u m m a ry

A pursuit of a native tradition of landscape archaeology seems to be a futile exercise at first. Since the 1960s human - environment relationships have been dominated by settlement studies which on one hand were influenced by German Siedlungsarchäologie and on the other by local historians who studied the medieval period. The final form of settlement studies was given in works of archaeologists such as W. Hensel, A. Dymaczewski, S. Kurnatowski and J. Kruk. Nowadays, regardless of its popularity abroad, any mention of landscape in Polish archaeological literature is scarce although some basic references can be found in regard to C. Tilley's groundbreaking work A phenomenology of landscape. The overall impression is that of a strangeness of landscape concept in Polish archaeology which is further enforced by some vague comments on its potential application in an undefined future. However, current practice of settlement archaeology stand in a strong contrast to these early studies. It was commonly assumed that recognition of settlement patterns was the first step in a much broader programme which ought to eventually help determine the effect of prehistoric settlement in shaping the landscape. 
This seeming contradiction has provoked a considerate insight into pre-war works which were often evoked as fundamental for understanding settlement processes, later developed by archaeologists. As early as 1920s, Polish geographers and medieval historians postulated research programme on cultural landscape within the framework of so-called historical geography. Inspired by anthropogeography of F. Ratzel, they attempted to determine the influence of environment on human history. From its beginnings, this school of thought put a strong emphasis on historical aspect of landscape studies which caused a modification of original ideas of anthropogeography with elements of evolutionism. The need for historical studies was justified with a long-term development of settlement patterns and economy which resulted in coexistence of phenomena coming from various periods. For example, remains of a medieval field system could be superimposed by recent land division resulting from parcelling out of great land estates. Thus, in order to understand current condition of a landscape it was deemed necessary to understand its origins and further developments of its use. It is crucial here to understand the role of settlement in landscape studies. The intertwined relationship between these two elements was a natural consequence of acceptance of certain theoretical assumptions. Within historical geography landscape was defined as the physical form of the terrain, consisting of elements such as landform, water system and vegetation cover. This so-called primeval or natural landscape was transformed over the course of mankind history into cultural landscape. As mentioned above, historical geography focused mainly on interactions between humans and natural environment thus special attention was paid to those spheres of activity which were directly related to environment. In this concept cultural activity in landscape was limited to settlement and economy. Consequently, cultural landscape was understood as any modification of a natural environment resulting from founding settlements and economical activity such as irrigation works (draining, river regulation, watering, soil fertilising etc.) and exploitation of natural resources which were affecting flora and fauna. Settlement studies were covering a broad spectrum of problems including migrations and diffusion, exploitation of natural resources, ethnical, demographic, social and economic changes as well as settlement location which was manifesting itself in a typological variety of villages.

Considering a strong influence of evolutionism, it seemed only natural to call archaeologists to join the project of landscape studies. Archaeology was regarded to be of primary importance for reconstructing landscapes which had not been heavily modified by activity of humans. It was believed that studies of prehistoric societies would help reconstruct relationships between people and their environment which were later obliterated by economical and social developments. A response to call for archaeological studies in landscape came reasonably quickly from Poznań university. In 1930 Jan Dylik, a student of two prominent professors: S. Pawłowski in geography and J. Kostrzewski in archaeology, obtained a doctorate for his thesis Osadnictwo epoki kamiennej w przełomowej dolinie Warty pod Poznaniem (Stone age settlement in a ravined Warta river valley near Poznań) which was probably the first work on prehistoric settlement in Polish archaeology. Dylik was a faithful follower of historical geography and his subsequent works created a framework for settlement studies. His studies were tackling two periods: Neolithic and Early Medieval and he formulated several thesis regarding prehistoric settlement patterns which laid foundations for later works. These can be summarised in the following points:

- the basic aim is to reconstruct a primary landscape and determine relationships between elements which were shaping it;

- possibilism, alternatively determinism as basic theories for understanding of human - environment relationships; 
- landscape reconstructed through settlement studies;

- settlement defined as habitation and economy, at the same time economic activity was prevailing at the expense of habitation; economic activity was understood as agriculture and pasturing thus a special attention was paid to settlement location, climate and soils;

- settlement and economic activity was limited to river valleys due to natural factors (location of light soils) and technical constraints imposed on prehistoric societies;

- any archaeological traces regardless of their character (settlement, cemetery, loose finds) were interpreted as settlement remains or traces of economical activity.

The programme of landscape studies proposed by Dylik can be seen as a further development of general ideas formulated by historical geography in prehistoric context. It remained in consensus with theoretical and methodological assumptions but also proposed new analytical tools which could be applied by prehistorians in their interpretations of archaeological data. This was certainly an innovative proposal and ahead of its times. Unfortunately after WWII Dylik shifted his research interests towards geomorphology and it took another thirty years before settlement archaeology had come to its mature form.

In 1960s. and 1970s. another graduate of Poznań university and a student of J. Kostrzewski, S. Kurnatowski published a series of articles which are still regarded as founding works for settlement studies. However, a comparison of main thesis with pre-war works demonstrates a continuity of ideas. At least in his first works Kurnatowski claimed that settlement studies ought to lead to reconstruction of landscapes. In this regard settlement studies had a four objectives:

- to establish chronological and spatial frameworks for human settlement in a given region;

- to determine ways and levels of environmental exploitation

- to estimate changes in cultural landscapes caused by natural and cultural processes;

- to date those settlement elements which were regarded as benchmarks for changes in a landscape.

Settlement studies examined changes over long time spans - in this case from Bronze Age to Early Medieval period and were filling chronological gaps in studies carried out earlier by Dylik. Within these frameworks Kurnatowski distinguished two settlement phases: the first from middle Bronze Age to Early Medieval period ( $10^{\text {th }}$ century) and the second beginning in $14^{\text {th }}$ and $15^{\text {th }}$ century (with a transitional period between $11^{\text {th }}$ and $13^{\text {th }}$ century) which practically continues up to date. The first phase was characterised by settlement limited to low grounds while human activity covered small patches of deforested areas. Settlement location was determined by distribution of light soils and economic activity had a limited effect on vegetation cover. Beyond settlement zones were vast areas of untouched primary woods. Signs of changes came in Early Medieval period with a very dense settlement network in river valleys, increase in arable land which lead to a destruction of forests, erosion of light soils and consequently an enforced move towards higher grounds beyond river valleys. This move was also enabled thanks to a technical breakthrough which made it possible to cut down forests so far untouched, cultivate heavy clay soils and create a dense settlement network outside river valleys which, as a result of those changes, turned into marshes. Thus in his studies, Kurnatowski demonstrated a limited effect of later prehistoric settlement on landscape. He also strongly believed that prehistoric settlement and agriculture was limited to river valleys due to technical constraints and it come only with Medieval technological developments that uplands were deforested, populated and turned into vast open landscapes. In comparison with earlier works it turns out that Kurnatowski's studies were merely a practical 
illustration of pre-war thesis about inaccessibility of uplands for prehistoric and early medieval agriculture which consequently led to a belief that settlement areas were limited to river valleys and changes were only possible when a society reached a certain technological level. The above statements permit formulation of a thesis that Polish settlement studies are deeply rooted in prewar ideas of landscape and it was mainly a matter of research fashions in 1970s that the term was abandoned for a more favoured 'settlement'.

Equally interesting is a comparison of these early works with their British and German peers. Two years after Dylik's thesis on Neolithic settlement, C. Fox published his seminal book The personality of Britain. His aim was to demonstrate the impact of geographical factors on migration and distribution of prehistoric societies on British Isles. Such a formulation of thesis clearly indicates the influence of anthropogeography. Fox argued that settlement pattern was shaped by vegetation cover and soils and illustrated it with an example of early farmers. According to him, Neolithic settlement was concentrated on sand, gravel, chalk and limestone. These were light, welldrained soils, covered with sparse vegetation and were easily accessible even to early farmers. Grazing prevented woodland regeneration which over a course of centuries changed gradually into a grassland and open areas. Thus settlement was focused on hills and higher parts of river valleys while lower terrains were avoided throughout prehistory due to their dense coverage with a damp oakwood which was growing on heavy clay soils. In general settlement was dispersed, concentrated on small clearings which were located on light soils. The major change was caused by a growing control of humans over environment which was expressed in a technical advancement resulting in an introduction of a wheelplough with mould board. This allowed a shift of settlement from light to heavy soils during Anglo-Saxon period which Fox called a 'valleyward movement'. The above analysis clearly demonstrates that Fox approved the main thesis of anthropogeography in regard to limited influence of prehistoric societies upon environment. What is even more interesting is that they were repeated more than twenty years later by a 'proper' father of landscape studies. W. Hoskins focused on the effect of human activity on shaping the English landscape. In his book he did not pay much attention to prehistoric settlement which was briefly summarised in one chapter. This attitude stemmed from a strong conviction that its influence was limited although it was still visible in some parts of England. According to Hoskins, after the departure of the Romans a reasonably orderly landscape was lost in weeds, scrubs and ruins thus returning to a natural state. For that reason Anglo-Saxons had to start their struggle with nature from the very beginning. Consequently, English landscape was given its final shape in the last fifteen centuries. Although it was never defined in his works, Hoskins understood landscape as a sum of cultural elements which were imposed on natural background as a result of long-term economic activity. Landscape tradition initiated by Hoskins is still very strong in British archaeology of historical period and is reflected in works of C. Taylor, M. Aston, A. Fleming or R. Muir. Only recently was this school of thought thoroughly analysed and criticised by M. Johnson who attempted to break through it, inspired by developments of landscape ideas in prehistoric archaeology.

Similar developments can be also noted in German Siedlungsarchäologie. According to H. Jankuhn who is regarded as its founder, one of the basic aims of settlement studies was to reconstruct cultural landscapes. Jankuhn's ideas were influenced by pre-war works of E. Wahle who was also inspired by Ratzel's concepts but insisted on a comprehensive analysis of factors shaping settlement. For Jankuhn, archaeological studies of settlement were complimentary to geography and history of settlement, the main difference being in data used by those disciplines. Archaeology 
was expected to provide information about elements which were shaping landscapes in those periods when both geography and history were lacking data. Jankuhn understood landscape as a result of changes introduced in an environment by human activity which set in motion natural processes (erosion, accumulation etc.) and also left cultural remains. Of crucial importance among the factors shaping settlement was economic activity and technological development which was visible in field systems, mining zones and working areas. Siedlungsarchäologie took for its starting point a detailed reconstruction of settlement network using a broad spectrum of archaeological sources such as villages, cemeteries, field systems, strongholds and other forms of defended settlement, cult/ ceremonial places, extraction and working zones, treasure deposits and so on. On that basis archaeologists could estimate the influence of humans on environment, that is the degree to which natural landscape was turned into a cultural. Jankuhn also accepted the assumption that technology imposed limitations to ways and methods of exploring natural resources which was expressed in a relationship between patterning of Neolithic settlement in regard to distribution of light soil and vegetation cover. This and other similarities with British ideas of landscape were also noted by contemporary German archaeologists who pointed out that Jankuhn was insisting strongly on off-site archaeology which took into consideration not only settlement but also its surroundings.

The above analysis demonstrates that ideas of landscape are deeply rooted in Polish tradition. It stemmed out of a historical geography and gave a foundation for settlement studies which flourished three decades later. Before WWII the Polish school of thought remained in a mainstream of European trends which in those days were shaped by anthropogeography of F. Ratzel and his student A. Hettner or possibilism of P. Vidal de la Blanche. Moreover, theoretical awareness of Polish researchers seemed to be more advanced than that of British founders of landscape archaeology. Unlike Hoskins, who openly expressed his dislike for theory, Dylik found it appropriate to discuss with main thesis of anthropogeography, offering his own thoughts and an original research programme on landscape. What can be regarded as history's sniggering is the fact that in Polish prehistory the term landscape was used thirty years earlier than in British where it was introduced in 1970's. Thus, if we take into consideration theoretical assumptions, interpretation of settlement processes which were shaping landscapes and implementation of those ideas in case studies, the differences between Central European and British traditions are minimal and irrelevant in culturehistory paradigm. On the contrary, one can observe numerous cases of striking similarities which were interesting fascinating so far as they were developed independently in various European centres. For that reason it can be said that there existed an international, archaeological communicative bond which shared similar theoretical assumptions. These developments were parallel and not secondary or borrowed. Within this paradigm landscape was understood as a sum of cultural elements which were imposed on a natural environment. Changes were caused by economic activity which consisted mainly of agriculture (eventually pasturing) in a variety of forms and advancements. Primitive techniques limited land use to light soils while settlement was dispersed and did not affect much the landscape. There was also a full agreement in regard to a Medieval technological breakthrough which caused enormous changes in landscape and resulted in its opening.

Differences between British and Central European archaeology can be certainly observed nowadays. However they do not arise out of incompatible traditions but attitudes of archaeologists. While traditional archaeology is still strong in Britain, there appear new theoretical proposals which seem to provide more suitable frameworks for current research problems. In particular, 
since the 1990's archaeologists were exploring ideas which were brought to attention mainly by French philosophers and resulted in phenomenological, hermeneutic and poststructuralist approaches. In archaeology these pursuits resulted in Tilley's book which is still regarded as a turning point in landscape archaeology. A co-existence of many different theoretical paradigms and clashing of various views and opinions ensures lively debates. Thus it is not surprising that British archaeology is leading in landscape studies. At the same time the mainstream Polish settlement archaeology has frozen to the spot in schemes which were worked out decades ago. A research model which was initiated in pre-war works and given its final form in 1960's and 1970's is still applied with only minor changes such as technological novelties (e.g. GIS or visualisation). Similarly, in German archaeology the shift from Siedlungsarchäologie to landscape archaeology was rather semantic and did not cause major changes in thinking about landscape. In this regard attitudes of pre-war Polish researchers who were searching for new directions were much closer to that of current British archaeologists. Those proposals are certainly outdated and if we can learn anything from these pre-war developments, it is mainly in research attitudes rather than theory and methodology. 